\title{
Assessment of Pichia anomala (strain K) efficacy against blue mould of apples when applied pre- or post-harvest under laboratory conditions and in orchard trials
}

\author{
Rachid Lahlali • Sébastien Massart • \\ Deborah De Clercq • M. Najib Serrhini • \\ Piet Creemers • M. Haïssam Jijakli
}

Received: 3 July 2007 / Accepted: 22 May 2008 / Published online: 13 June 2008

(C) KNPV 2008

\begin{abstract}
The yeast Pichia anomala strain K was selected in Belgium from the apple surface for its antagonistic activity against post-harvest diseases of apples. The efficacy of this strain against $P$. expansum was evaluated in the laboratory in three scenarios designed to mimic practical conditions, with different periods of incubation between biological treatment, wounding of fruit surface, and pathogen inoculation. Higher protection levels and higher final yeast densities were obtained when the applied initial concentration was $1 \times 10^{8} \mathrm{cfu} \mathrm{m}^{-1}$ than when it was only $1 \times 10^{5} \mathrm{cfu}$ $\mathrm{ml}^{-1}$. The protection level correlated positively with the yeast density determined in wounds and was influenced by apple surface wetness. In orchard trials spanning two successive years, biological treatment
\end{abstract}

R. Lahlali · S. Massart • D. De Clercq · M. H. Jijakli $(\bowtie)$

Plant Pathology Unit, Gembloux Agricultural University,

Passage des Déportés 2,

5030 Gembloux, Belgium

e-mail: Jijakli.h@fsagx.ac.be

M. N. Serrhini

Department of Phytopathology,

Ecole National d'Agriculture de Meknès,

B P S/40 50001 Meknès, Morocco

P. Creemers

Proefcentrum Fruitteelet Mycology,

De Brede Akker 13,

3800 Sint-Truiden, Belgium against $P$. expansum, based on a powder of $P$. anomala strain $\mathrm{K}\left(1 \times 10^{7} \mathrm{cfu} \mathrm{ml}^{-1}\right), \beta$-1,3-glucans (YGT $2 \mathrm{~g}$ $\left.\mathrm{l}^{-1}\right)$, and $\mathrm{CaCl}_{2} \cdot 2 \mathrm{H}_{2} \mathrm{O}\left(20 \mathrm{~g} \mathrm{l}^{-1}\right)$, was applied to apples pre- or post-harvest under practical conditions and its effect compared with standard chemical treatments. The first year, the highest reduction (95.2\%) against blue decay was obtained by means of four successive fungicide treatments and the next-highest level (87.6\%) with pre-harvest high-volume spraying of the threecomponent mixture 12 days before harvest. The second year, the best results were obtained with post-harvest Sumico (carbendazim 25\% and diethofencarb 25\%) treatment and post-harvest biological treatment, both by dipping the apples, 88.3 and $56.3 \%$ respectively. A density threshold of $1 \times 10^{4} \mathrm{cfu} \mathrm{cm}^{-2}$ of strain $\mathrm{K}$ on the apple surface seemed to be required just after harvest for high protective activity, whatever the method and time of application. In the case of pre-harvest biological treatments, variations in meteorological conditions between the 2 years may have considerably affected strain $\mathrm{K}$ population density and its efficacies.

Keywords Biological control P. expansum .

Pre-harvest application - Three-component mixture

\section{Introduction}

Penicillium expansum is responsible for blue mould of harvested apples, worldwide (Spotts et al. 1998). Its infection is initiated mainly at wounds inflicted 
during harvest and handling of apples. Fungicide treatment is the most common strategy used to control this pathogen, but the intensive use of fungicides such as thiabendazole (TBZ) and imazalil (IMZ) has led to the emergence of resistant strains of $P$. expansum (Spotts and Cervantes 1986; Vinãs et al. 1993; Guetsky et al. 2001). This fact, associated with growing public concern for human health and environmental hazards, highlights the need to develop alternative methods for controlling post-harvest diseases of apples (Wisniewski and Wilson 1992; Smilanick 1994).

Several microorganisms are reported to colonise wound sites of apples and to compete with the pathogen (Benbow and Sugar 1999; Janisiewicz and Korsten 2002). In practice, effective biocontrol has been achieved by applying the biocontrol agent (BCA) after harvest by dipping or drenching (Jijakli et al. 2002). Pre-harvest application of BCAs has scarcely been studied (Benbow and Sugar 1999; Leibinger et al. 1997), although it shows high potential for pathogen biocontrol under practical conditions (Teixidõ et al. 1999). As most BCAs of post-harvest apple pathogens have been isolated from the apple surface, they should be able to adapt to the environmental conditions existing on this surface (chemical treatment, sun light, rain, dry conditions). Ippolito and Nigro (2000) have stressed the ability of some BCAs to pre-colonise the fruit surface or wounds immediately before harvest, so that wounds inflicted during harvest can be colonised by the antagonist prior to colonisation by the pathogen. Furthermore, several studies (Janisiewicz 1988; Wisniewski and Wilson 1992) have shown the ability of some BCAs to colonise wounds for long periods under dry conditions and to produce extracellular components which improve their survival and decrease colonisation of sites by pathogenic fungi.

The yeast Pichia anomala strain K was previously selected for its high antagonistic activity against Botrytis cinerea and P. expansum on Golden Delicious apples (Jijakli et al. 1999; Jijakli and Lepoivre 1998). The protective activity of strain K under laboratory conditions is strongly related to efficient colonisation of the apple wounds prior to infection by the pathogen (Jijakli 1996). This emphasises the importance of applying BCAs in the field prior to wounding during harvest (Jijakli et al. 1999, 1993; Spotts et al. 1998).
The objective of this work was to evaluate the ability of strain $\mathrm{K}$ to colonise the apple surface and to protect apples against $P$. expansum after pre-harvest application. For this purpose, we have conducted experiments (1) to evaluate the reproducibility of strain $\mathrm{K}$ recovery from the apple surface in smallscale laboratory tests, (2) to assess both yeast population density and biocontrol efficacy under three scenarios reflecting practical conditions, and (3) to assess the biocontrol efficacy when strain $\mathrm{K}$ was applied pre- or post-harvest in orchard trials spanning two successive growing seasons.

\section{Materials and methods}

\section{Organisms}

Pichia anomala (strain K) was isolated from the surface of cv. Golden delicious apples at the Plant Pathology Unit (Gembloux Agricultural University, Belgium) and identified by the Industrial Fungi \& Yeast collection (BCCMTM/MUCL, Belgium). Stock cultures were stored at $4^{\circ} \mathrm{C}$ on Potato Dextrose Agar (PDA, Merck, Darmstadt, Germany) plates. Before an experiment, strain $\mathrm{K}$ was cultured at $25^{\circ} \mathrm{C}$ for three successive generations on PDA with an interval of $24 \mathrm{~h}$ (Jijakli and Lepoivre 1998). A 10 day-old colony of $P$. expansum grown on PDA medium was used to obtain spore suspensions in sterile distilled water (SDW) containing $0.05 \%(\mathrm{wt} / \mathrm{v})$ Tween $20 \mathrm{l}^{-1}$. Spore suspensions were adjusted to $1 \times 10^{5}$ spores $\mathrm{ml}^{-1}$ using a Bürker cell.

Monitoring of strain K population density on the apple surface under laboratory conditions

Apple fruits hand-harvested at commercial maturity (cv. Golden Delicious) were surface-sterilised by soaking in sodium hypochlorite solution $(10 \%)$ for 2 min and rinsed twice in SDW. After drying, the fruits were treated by dipping into strain $\mathrm{K}$ suspensions $(1 \times$ $10^{5}, 1 \times 10^{6}, 1 \times 10^{7}$ or $1 \times 10^{8} \mathrm{cfu} \mathrm{m}^{-1}$ ) for $2 \mathrm{~min}$, and then kept at room temperature. After $24 \mathrm{~h}$, four apples per treatment were washed in $11 \mathrm{KBP}$ buffer $\left[\mathrm{KH}_{2} \mathrm{PO}_{4}\right.$ $(0.05 \mathrm{M}), \mathrm{K}_{2} \mathrm{HPO}_{4}(0.05 \mathrm{M})$ and $0.05 \%(\mathrm{wt} / \mathrm{v})$ Tween $80, \mathrm{pH} 6.5]$ (one plastic bag per treatment) on a rotary shaker for $20 \mathrm{~min}$ at $120 \mathrm{rpm}$. Four serial 10-fold dilutions were prepared from $1 \mathrm{ml}$ washing buffer and 
were plated in triplicate on PDA medium. Petri dishes were kept at $25^{\circ} \mathrm{C}$ for 2 to 3 days. This experiment was repeated twice. The surface area of the apple was calculated as follows: [Area $\left(\mathrm{cm}^{2}\right)=0.488 \times$ volume of displaced water $(\mathrm{ml})+66.1]$ (De Clercq et al. 2003; Massart et al. 2005). Population sizes were expressed as $\mathrm{cfu} \mathrm{cm}^{-2}$. The effect of the initial concentration applied on the population yeast density on apple fruit surface $\left(\mathrm{cfu} \mathrm{cm}^{-2}\right.$ ) was determined using GLM procedure of SAS software (SAS Institute, Inc, Cary, NC, USA); when the overall effect was significant Newman-Keuls test was then used to compare individual treatment means at the level of $P=0.05$.

Assessment of strain K efficacy in relation to population density under laboratory conditions

Disinfected fruits were soaked in a suspension of strain $\mathrm{K}$ at $1 \times 10^{5}$ or $1 \times 10^{8} \mathrm{cfu} \mathrm{m}^{-1}$ for $2 \mathrm{~min}$. Treated fruits were wounded in four equidistants points at the equatorial zone $(2-3 \mathrm{~mm}$ diam, $4 \mathrm{~mm}$ deep) using a cork borer and the pathogen inoculated according to three scenarios (Table 1): (1) wounding immediately after antagonist application, followed by pathogen inoculation or yeast cell recovery $24 \mathrm{~h}$ later; (2) wounding $24 \mathrm{~h}$ after antagonist application, immediately followed by pathogen inoculation or yeast cell recovery; (3) wounding $24 \mathrm{~h}$ after antagonist treatment, followed by pathogen inoculation or yeast cell recovery $24 \mathrm{~h}$ later. For each treatment (each antagonist concentration and scenario combination), eight apples were used. Among them, four apples (corresponding to a total of 16 wounds) were inoculated with the pathogen. From the other four, yeast cells were recovered. This experiment was repeated twice.

For yeast cell recovery, wound sites were cut out and placed in $10 \mathrm{ml}$ PKB. After washing for $1.5 \mathrm{~min}$

Table 1 The sequence of treatments following three scenarios performed on apple fruits already treated with $P$. anomala strain $\mathrm{K}$ at $10^{7} \mathrm{cfu} \mathrm{ml}^{-1}$

\begin{tabular}{|c|c|c|}
\hline \multirow[t]{2}{*}{ Scenarios } & \multicolumn{2}{|l|}{ Sequence of treatments } \\
\hline & Apple wounding & $\begin{array}{l}\text { Yeast recovery or } \\
\text { pathogen inoculation }\end{array}$ \\
\hline Scenario I & $\begin{array}{l}\text { Immediately after yeast } \\
\text { treatment }\end{array}$ & $24 \mathrm{~h}$ after wounding \\
\hline Scenario II & $24 \mathrm{~h}$ after yeast treatment & Immediately after wounding \\
\hline Scenario III & $24 \mathrm{~h}$ after yeast treatment & $24 \mathrm{~h}$ after wounding \\
\hline
\end{tabular}

with an UltraTurrax T25, $100 \mu$ of serial 10-fold dilutions of individual suspensions were plated in triplicate on Petri dishes. Colonies were counted after incubation at $25^{\circ} \mathrm{C}$ for 2 to 3 days. Population sizes were expressed as cfu wound ${ }^{-1}$.

For pathogen inoculation, $10 \mu \mathrm{l}$. expansum cell suspensions $\left(1 \times 10^{5}\right.$ spores $\left.\mathrm{ml}^{-1}\right)$ was inoculated to each wound. Inoculated fruits were then kept at $20^{\circ} \mathrm{C}$ for 7 to 11 days. Control efficacy was calculated on the basis of the differences in lesion diameters between antagonist-treated and water-treated wounds. This experiment was repeated twice. Analysis of variance (ANOVA) was performed separately for each scenario to determine the effect of strain $\mathrm{K}$ population yeast density (cfu wound ${ }^{-1}$ ) on control efficacy (\%) using GLM procedure of SAS software (SAS Institute, Inc, Cary, NC, USA). When ANOVA revealed significant differences, Newman-Keuls test was used to compare individual treatments.

Pre- and post-harvest application of Pichia anomala strain $\mathrm{K}$ under practical conditions

Experiments were carried out in collaboration with the Royal Fruit Research Station of Gorsem (Belgium) over two successive years, in an experimental cv. Golden Delicious orchard (planted in 1995) located in Melveren (Belgium). Temperature, rain, and relative humidity were monitored using a meteorological station located in the orchard. Daily average temperature $\left({ }^{\circ} \mathrm{C}\right)$ and total rainfall $\left(1 \mathrm{~m}^{-2}\right)$ were calculated. Trees of cv. Golden Delicious ( 8 per treatment) were treated with a powder of strain $\mathrm{K}$ $\left(10^{7} \mathrm{cfu} \mathrm{ml}^{-1}\right)$ produced by CWBI (Centre Walloon de Biotechnologie, Université de Liège, Belgium and stored at $4^{\circ} \mathrm{C}$ for maximum 1 week before its application) supplemented with $\beta$-1,3-glucans (Ohly, Germany) (YGT, $2 \mathrm{~g} \mathrm{l}^{-1}$ ) and $\mathrm{CaCl}_{2} \cdot 2 \mathrm{H}_{2} \mathrm{O}$ (Merck, Belgium) $\left(20 \mathrm{~g} \mathrm{l}^{-1}\right)$. This three-component mixture was applied 12, 5, or 2 days before harvest in the first year and 15,7 , or 3 days before harvest in the second year, by spraying at low volume $\left(300 \mathrm{l} \mathrm{ha}^{-1}\right)$ or high volume $\left(1000 \mathrm{l} \mathrm{ha}^{-1}\right)$. Apples from field treatments (six sprayed batches) and three untreated batches (from trees without chemical or biological treatment) were artificially wounded using an appropriate cork borer just after harvest ( 4 wounds per apple, 2 to $3 \mathrm{~mm}$ diam, $4 \mathrm{~mm}$ deep). Post-harvest treatment performed with a three-component mixture containing 
strain K was applied to two batches of the untreated apples 1 day after harvest by dipping fruits in a plastic 6501 container (Norah plastics Industriepark Wolfstee, Herentals, Belgium) for $2 \mathrm{~min}$ or drenching at constant pressure of 2 bars $\left(101\right.$ ton $\left.^{-1}\right)$. Two days after harvest, all batches were artificially inoculated with $P$. expansum $\left(1 \times 10^{5}\right.$ spores $\left.\mathrm{ml}^{-1}\right)$. Three controls were carried out as follows: (1) a standard programme based on pre-harvest chemical treatments [spraying with Bavistin (carbendazim 50\%), Phytocap (captan $80 \%$ ), Sumico (carbendazim 25\% and diethofencarb 25\%), and Euparen (tolylfuanid 50.5\%)] respectively 4, 3, 2, and 1 weeks before harvest; (2) a standard post-harvest treatment with Sumico $\left(1 \mathrm{~g} \mathrm{l}^{-1}\right)$ by dipping; (3) the third batch of untreated apples. The whole experiment was carried out on four replicates (one replicate containing 12.5) per treatment using a single group of trees that had received the field trial treatments. In both years, the apples were successively stored at $1^{\circ} \mathrm{C}(15$ days $), 15^{\circ} \mathrm{C}(1$ month $)$, and $20^{\circ} \mathrm{C}$ (15 days). The incubation of apples fruit at higher temperature than $1{ }^{\circ} \mathrm{C}$ was performed in order to accelerate the development of symptoms.

After the storage period, the number of infected fruits was recorded and incidence of decayed fruits was estimated for each strain $\mathrm{K}$ pre- or post-harvest trials. One-way ANOVA was conducted to determine treatment effects on the incidence (\%) of decayed fruit using SAS software (SAS Institute, Inc, Cary, NC, USA). Arcsin-square root transformation was performed before ANOVA. Statistical significance was judged at $P \leq 0.05$ level and Newman-Keuls test was used to compare treatment means.

Monitoring of strain $\mathrm{K}$ after application under practical conditions

Different treatments were applied to apples as described above, but the fruits were not wounded or inoculated with pathogens. They were stored at $1{ }^{\circ} \mathrm{C}$ for 1 month. After this period, 8 apples per treatment were separately washed for $20 \mathrm{~min}$ in $250 \mathrm{ml}$ PKB. The washing suspensions of the 8 fruits were pooled and mixed, serially diluted, and plated on a semiselective medium consisting of PDA supplemented with $12.5 \mathrm{mg} \mathrm{l}^{-1}$ hygromycin $\mathrm{B}, 0.25 \mathrm{mg}^{-1}$ TMTD (containing thirame as the active ingredient), and $5 \mathrm{mg} \mathrm{l}^{-1}$ Sumico (including $1.25 \mathrm{mg} \mathrm{l}^{-1}$ carbendazim and $1.25 \mathrm{mg}^{-1}$ diethofencarb). After 3 days of incubation, white yeast colonies were counted. Pichia anomala strain $\mathrm{K}$ population ( $\mathrm{cfu} \mathrm{cm}^{-2}$ ) was logtransformed to improve homogeneity.

\section{Results}

Population density of strain $\mathrm{K}$ in laboratory

Results are presented in Fig. 1. ANOVA revealed a significant effect $(P \leq 0.05)$ of initial antagonist application concentration on the density of strain $\mathrm{K}$ (cfu $\mathrm{cm}^{-2}$ ) on the apple fruit surface. A density higher than $1 \times 10^{4} \mathrm{cfu} \mathrm{cm}^{-2}$ on the apple surface was obtained only with the highest initial antagonist concentration applied $\left(1 \times 10^{8} \mathrm{cfu} \mathrm{ml}^{-1}\right)$. When the initial antagonist application concentration was $1 \times 10^{5} \mathrm{cfu} \mathrm{m}^{-1}$, the density was $<2 \times 10^{3} \mathrm{cfu} \mathrm{cm}^{-2}$ on intact apple surfaces. These two extreme initial concentrations were selected for further experiments.

Population density and control efficacy under three scenarios

Scenario I A higher population density of strain K was recorded after application of $1 \times 10^{8} \mathrm{cfu} \mathrm{m}^{-1}$ than after application of $1 \times 10^{5} \mathrm{cfu} \mathrm{ml}^{-1}$ (Fig. 2a). The corresponding control efficacies were $71.1 \%$ and $59.6 \%$ (Fig. 2b).

Scenario II Colonies were detected in wounds only for the treatment with strain $\mathrm{K}$ at $1 \times 10^{8} \mathrm{cfu} \mathrm{ml}^{-1}$

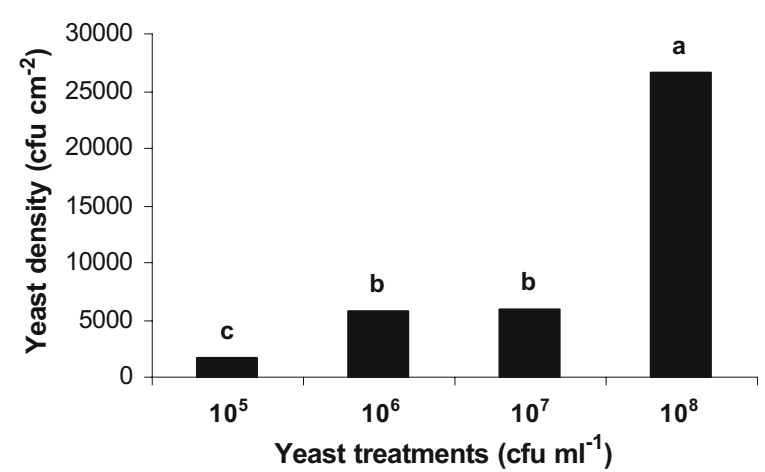

Fig. 1 Population density of $P$. anomala strain $\mathrm{K}\left(\mathrm{cfu} \mathrm{cm}^{-2}\right.$ on intact apple surface) $24 \mathrm{~h}$ after application, in relation to the initial applied concentration ( $\mathrm{cfu} \mathrm{ml}^{-1}$ ). Treatments having the same letter are not significantly different according to Newman-Keuls test $(P \leq 0.05)$ 


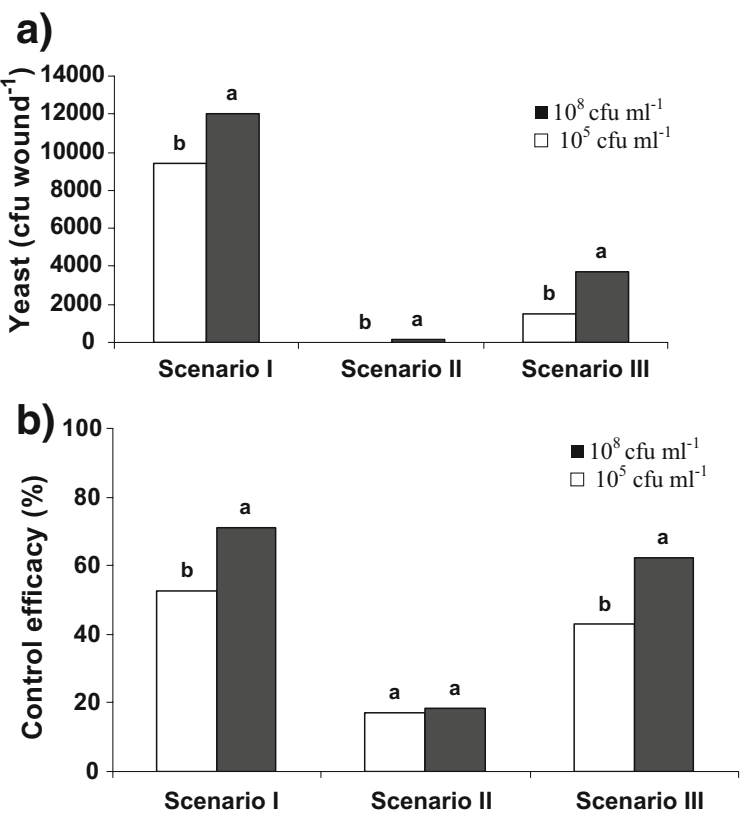

Fig. 2 Population densities (a) and control efficacy (b) obtained after application of $P$. anomala strain $\mathrm{K}$ at $1 \times 10^{8}$ or $1 \times 10^{5} \mathrm{cfu}$ $\mathrm{ml}^{-1}$ to the apple surface in three scenarios mimicking practical conditions. The scenarios differed by the timing of biological treatment and subsequent wounding. Results obtained after treatments sharing a common letter did not differ significantly according to Newman-Keuls test $(P \leq 0.05)$

(Fig. 2a). Whatever the initial concentration applied, strain K population density was much lower than the other two scenarios. For both application concentrations, the efficacy against $P$. expansum did not exceed $30 \%$ (Fig. 2b).

Scenario III Here again, the number of detected $P$. anomala colonies was higher when the initial concentration applied was $1 \times 10^{8} \mathrm{cfu} \mathrm{ml}^{-1}$ than when it was $1 \times 10^{5} \mathrm{cfu} \mathrm{m}^{-1}$ (Fig. 2a). The corresponding control efficacies against $P$. expansum were respectively $62.1 \%$ and $42.8 \%$ (Fig. $2 b$ ).

Overall, there was a significant $(P=0.034)$ correlation between $P$. anomala population density per wound $\left(\mathrm{x}, \mathrm{cfu} \mathrm{cm}^{-2}\right)$ and its obtained control efficacy (y, \%) against $P$. expansum $(y=4.92 \times 2(0.13)-7.54 \times$ $\left.(0.52)+16.30(0.18), R^{2}=0.89\right)$ (Fig. 3).

Pre- and post-harvest application of $P$. anomala strain $\mathrm{K}$

Year 1 considering all the trials carried out, the best control against $P$. expansum was obtained with the pre-harvest chemical treatment of four successive applications of fungicide (Table 2). Pre-harvest application of strain $\mathrm{K}$ mixture led to a significant reduction of $P$. expansum decay ranging from 39.9 to $87.8 \%$. The greatest reduction $(87.8 \%)$ was obtained with a high-volume spray 12 days before harvest. This reduction level was slightly (but not significantly) higher than those obtained with the standard postharvest chemical treatment. When strain $\mathrm{K}$ was applied post-harvest, no significant protection was observed. With the high-volume spray applied 12 days or 2 days pre-harvest, the population densities of strain $\mathrm{K}$ on the apple surface just before artificial pathogen inoculation were $1.7 \times 10^{4}$ or $3.1 \times 10^{4} \mathrm{cfu} \mathrm{cm}^{-2}$, respectively (Fig. 4a). The density level on apples treated by post-harvest dipping but not yet inoculated with the pathogen never reached $10^{4} \mathrm{cfu} \mathrm{cm}^{-2}$.

Year 2 The suspension containing strain $\mathrm{K}$ was always mixed before each treatment to ensure homogeneity during post-harvest application. All pre- and post-harvest applications of strain $\mathrm{K}$ significantly $(P \leq 0.05)$ reduced the incidence of blue mould; the best results were obtained with the standard post-harvest chemical treatment followed by pre-harvest chemical treatment and post-harvest strain $\mathrm{K}$ treatment (Table 2). For pre-harvest treatment, the greatest reductions obtained were $46.7 \%$ for chemical treatment and $42.0 \%$ for the high-volume spray of strain K, 3 days before harvest. In the case of post-harvest dipping of the apples, density of $1.6 \times$ $10^{4} \mathrm{cfu} \mathrm{cm}^{-2}$ of strain $\mathrm{K}$ was recorded on the apple surface just before pathogen inoculation (Fig. 4b). In the case of pre-harvest treatments (high-volume spray 12 or 2 days before harvest), lower densities ( $<10 \mathrm{cfu}$ $\mathrm{cm}^{-2}$ ) were observed at this time.

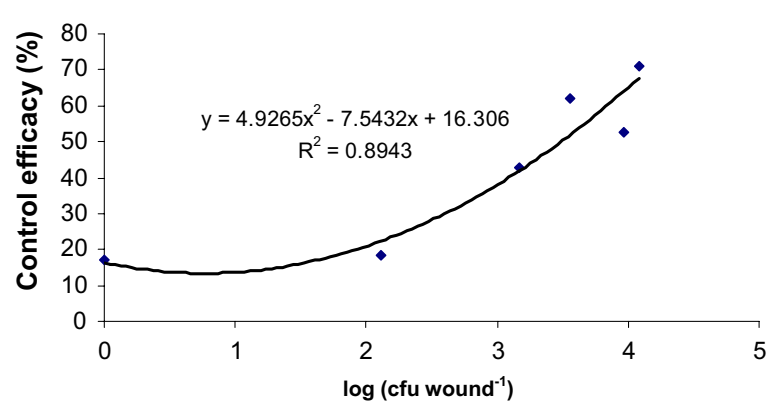

Fig. 3 Relationship between strain K efficacy (\%) and its population density (cfu wound ${ }^{-1}$ ) in laboratory trials 
Table 2 Efficacy of biocontrol agent Pichia anomala strain K and chemical treatments against blue mould in relation to the method and time of application

\begin{tabular}{|c|c|c|}
\hline \multirow[t]{2}{*}{ Treatment } & \multicolumn{2}{|c|}{ Infected fruits $(\%)$} \\
\hline & Year 1 & Year 2 \\
\hline \multicolumn{3}{|l|}{ Pre-harvest ${ }^{\mathrm{a}}$} \\
\hline Biological, LVS (12 or 15 days) & $15.0 \mathrm{~d}^{\mathrm{b}, \mathrm{c}}$ & $68.3 \mathrm{c}$ \\
\hline Biological, HVS (12 or 15 days) & $11.3 \mathrm{e}$ & $60.4 \mathrm{~d}$ \\
\hline Biological, LVS (5 or 7 days) & $52.9 \mathrm{bc}$ & $89.6 b$ \\
\hline Biological, HVS (5 or 7 days) & $58.9 \mathrm{~b}$ & $94.0 \mathrm{~b}$ \\
\hline Biological, LVS (2 or 3 days) & $53.3 \mathrm{bc}$ & $95.6 \mathrm{~b}$ \\
\hline Biological, HVS ( 2 or 3 days) & $43.3 \mathrm{c}$ & $56.5 \mathrm{e}$ \\
\hline Standard chemical ${ }^{\mathrm{d}}$ & $3.6 \mathrm{f}$ & $51.8 \mathrm{f}$ \\
\hline \multicolumn{3}{|l|}{ Post-harvest } \\
\hline Biological, dipping & $98.4 \mathrm{a}$ & $42.2 \mathrm{~g}$ \\
\hline Biological, drenching & $99.2 \mathrm{a}$ & $43.2 \mathrm{~g}$ \\
\hline Standard chemical ${ }^{\mathrm{e}}$ & 13.0de & $10.1 \mathrm{~h}$ \\
\hline \multicolumn{3}{|l|}{ Control } \\
\hline Untreated apples & $98.9 \mathrm{a}$ & $98.5 \mathrm{a}$ \\
\hline
\end{tabular}

LVS Low volume spray, HVS high-volume spray

${ }^{a}$ In parentheses: time of treatment in days before harvest (first number, year 1; second number, year 2)

${ }^{b}$ Data are the mean of four replicates of incidence of decayed fruits (\%) calculated based on number of infected fruits as compared to total fruits for each treatment

${ }^{\mathrm{c}}$ This column shows when differences are significant $(P<0.05)$; if two results share a common letter, the difference between them is not significant according to Newman-Keuls test

${ }^{\mathrm{d}}$ Spraying of Bavistin, Phytocap, Sumico, and Euparen at the authorised Belgian doses, respectively 4, 3, 2, and 1 week before harvest

${ }^{\mathrm{e}}$ Dipping in Sumico $\left(1 \mathrm{~g} \mathrm{l}^{-1}\right)$

\section{Meteorological conditions}

During the pre-harvest trial period in the first year, average daily temperatures before harvest were between 18 and $25^{\circ} \mathrm{C}$. Dry weather was observed at the orchard except for one heavy rainfall lasting $10 \mathrm{~h}$ with a maximal intensity of $1.41 \mathrm{~m}^{-2} \mathrm{~h}^{-1}$ (data not shown). The relative humidity remained high (93$100 \%$ ) from 12 to 5 days before harvest. During the pre-harvest trial in the second year, temperatures were lower, ranging from 12 to $19^{\circ} \mathrm{C}$. The weather was rainy, with four heavy rainfall events (up to $51 \mathrm{~m}^{-2} \mathrm{~h}^{-1}$ ).

\section{Discussion}

Research on biological control of post-harvest diseases of fruit has focused on applying a BCA after harvest under controlled environment conditions
(Wisniewski and Wilson 1992). Few studies have focused on controlling post-harvest decay by means of pre-harvest application. In our laboratory tests, the best control observed in scenarios I and III was associated with apples displaying a yeast density exceeding $1 \times 10^{4} \mathrm{cfu} \mathrm{cm}^{-2}$ on the intact apple surface. This population density was obtained by applying the BCA at the initial concentration of $1 \times 10^{8} \mathrm{cfu} \mathrm{ml}^{-1}$. Scenario III (Fig. 2) was designed to reproduce conditions corresponding to pre-harvest application of yeast followed by wounding, which can occur during harvest or subsequent handling, and possible subsequent pathogen infection. Our three scenarios took into account different levels of wetness on the apple fruit surface when applying the yeast. Our results suggest that the wetness of the apple fruit surface affects the yeast population density and correspondingly influences the biocontrol efficacy, since a wet apple surface allowed better growth of strain $\mathrm{K}$ and hence better control. On the other hand, it is well known that wound healing, due to callose apposition and phenolic compound production, can create a barrier against pathogen infection such as $P$. expansum or B. cinerea (Lakshminarayana et al.

\section{(a) Year 1}

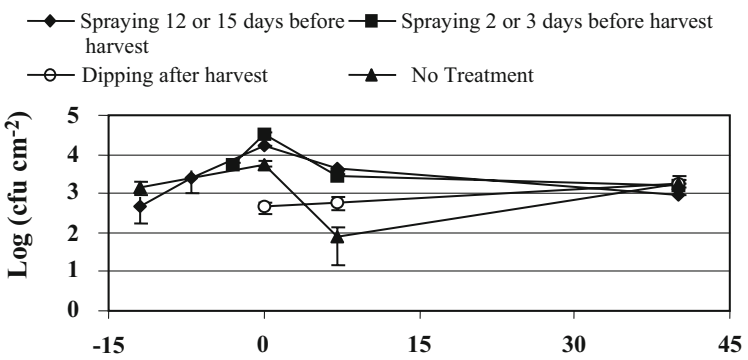

(b) Year 2

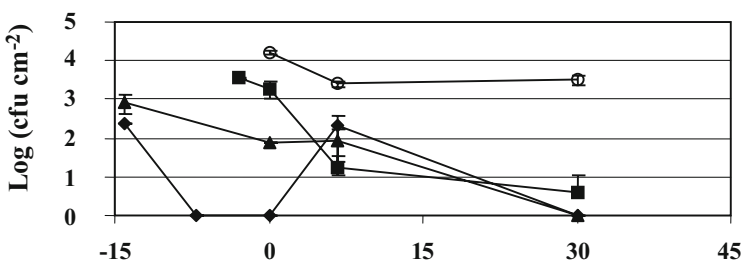

Time before harvest (days)

Fig. 4 Density of P. anomala strain $\mathrm{K}\left(1 \times 10^{7} \mathrm{cfu} \mathrm{m}^{-1}\right)$ recorded on the fruit surface after application at either as a high-volume spray 12 or 2 days before harvest in year 1 , and 15 or 3 days in year 2, or by post-harvest dipping. Vertical bars are standard errors on the respective means expressed as log (cfu $\mathrm{cm}^{-2}$ on the apple surface) 
1987). However, these authors demonstrated that this phenomenon occurred 4 days after wounding. In the three scenarios, inoculation was followed immediately after wounding (scenario 1) or $24 \mathrm{~h}$ after wounding (scenarios 2 and 3). This period of incubation does not allow the healing process of the wound. Present results also highlight the need to understand the behaviour of strain $\mathrm{K}$ under in vitro and in vivo conditions with respect to major environmental factors such as temperature and relative humidity, in order to achieve reliable control when applied preharvest. These results are similar to those of Mercier and Wilson (1994), who reported that a dry environment for 1 day-old wounds may affect the growth of both $B$. cinerea and the antagonist $C$. oleophilea on apples. These researchers found the population density of the antagonist to increase quickly when water was periodically applied to the wounded sites on the fruit. They proposed that humidity may be a factor limiting the development of the antagonist and its target. Additionally, Wilson et al. (1993) underlined the importance of applying BCAs at the various stages of fruit handling that could result in wounding.

In field trials in two successive years, there was considerable variability in population densities of strain $\mathrm{K}$ and its biocontrol efficacies between the 2 years. Despite this variability, field results confirmed that strain K population density on the apple fruit surface affects the biocontrol efficacy against $P$. expansum. Whatever the experimental conditions, a density threshold of $1 \times 10^{4} \mathrm{cfu} \mathrm{cm}^{-2}$ on the apple surface seemed to be required at the time when the pathogen was inoculated. At this density, strain K significantly reduced of the incidence of blue mould. When the strain $\mathrm{K}$ density was below $1 \times 10^{4} \mathrm{cfu} \mathrm{m}^{-1}$, the reduction in the disease incidence was also significant but was small. These results are in agreement with those reported by De Clercq et al. (2003).

The first year results showed no significant biocontrol efficacy when strain $\mathrm{K}$ was applied post-harvest, which contradicts previous studies (Jijakli et al. 2002) and also the second year results. This may be due to an artifact: during the first year, the strain $\mathrm{K}$ cells tended to sink to the bottom of the inoculum (this was confirmed visually after the first year) over time, and the apples were not therefore treated with the calculated concentration of cells, but with a much lower one. We took action to avoid this problem the second year, by regularly mixing the strain $\mathrm{K}$ suspension.
Other factors are likely to have contributed to yearto-year variation. Numerous authors have evaluated the efficacy of BCAs against post-harvest diseases under field conditions over a single year (Benbow and Sugar 1999; Chand-Goyal and Spotts 1996; Leibinger et al. 1997), and highly variable results have been obtained in multi-year field experiments where a BCA against B. cinerea was applied (Kovach et al. 2000, Sutton et al. 1997; Tronsmo and Dennis 1977). Ippolito and Nigro (2000) stressed that successful pre-harvest application of an antagonist depends on many factors such as rain, wind, temperature, and relative humidity. Elad and Kirshner (1992) likewise suggested that microclimatic conditions have a greater effect than nutrient availability on the establishment of Trichoderma on the phylloplane. Such factors may affect the viability of the antagonist and its efficacy. It is therefore mandatory to monitor meteorological conditions during trials. During the first year, only one heavy rainfall was recorded in the orchard, lasting for $10 \mathrm{~h}$ with a maximal intensity of $1.41 \mathrm{~m}^{-2} \mathrm{~h}^{-1}$. The second year, four heavy rainfalls (up to $5 \mathrm{l} \mathrm{m}^{-2}$ $\mathrm{h}^{-1}$ ) were recorded. Rain might wash off a BCA and chemical residues. The daily average temperature range was also different between the first and second years: from 18 to $25^{\circ} \mathrm{C}$ the first year and from 12 to $19^{\circ} \mathrm{C}$ the second year. As strain $\mathrm{K}$ development is temperature-dependent with an optimum between 20 and $25^{\circ} \mathrm{C}$ (Lahlali 2006), the lower temperature range observed in the second year might have hindered development of the strain $\mathrm{K}$ population. Teixidõ et al. (1999) reported that the $C$. sake population density reached after $48 \mathrm{~h}$ in orchards was higher in a growing season with an average temperature of $25^{\circ} \mathrm{C}$ than in one with an average temperature of $32^{\circ} \mathrm{C}$. Present experiments showed that the strain $\mathrm{K}$ population density reached its highest level in year 1 when the average temperatures were close to the optimal temperature required for strain $\mathrm{K}$ development. Thus, temperature and rainfall in the first year were more favourable for development of strain $\mathrm{K}$ on the apple surface and led to greater biocontrol efficacy when applied pre-harvest. Lahlali (2006) reported a greater effect of humidity than temperature on the strain $\mathrm{K}$ population density on the apple surface under controlled laboratory conditions. Furthermore, Guetsky et al. (2001) reported effects of temperature, relative humidity, and spray timing combinations on the biocontrol efficacy of Bacillus mycoides and Pichia 
guilermondii against Botrytis cinerea under laboratory conditions.

In this work, $P$. anomala strain $\mathrm{K}$ in pre- and postharvest treatments was applied in a mixture with calcium chloride $\left(\mathrm{CaCl}_{2}\right)$ and $\beta$-1,3-glucans in order to reinforce its biocontrol efficacy. McLaughlin et al. (1990) reported that calcium salts improved the efficacy of the yeast BCA against Botrytis and Penicillium rots of apples. They suggested that the effect of calcium was due to some interaction with the yeast or its metabolic products at the wound site. However, a direct effect of calcium on the pathogen or the fruit tissue was also highlighted in others studies (Wisniewski et al. 1995; Droby et al. 1997). Jijakli and Lepoivre (1998) showed that the presence of $\beta$-1,3-glucans with $P$. anomala strain K stimulated the yeast glucanase activity and consequently increased the efficacy against wound pathogens. However, it was not possible to completely discard an eliciting effect of this molecule under practical conditions.

In conclusion, the present results underscore the necessity of developing an appropriate formulation for successful and reliable pre-harvest application of a $\mathrm{BCA}$. This formulation will have to protect strain $\mathrm{K}$ cells against detrimental climatic factors and allow them to reach a population level sufficient for reliable disease control, highlighting the need to study the impact of ecological factors on the antagonist. Future investigations will focus on the impact of ecological factors on the growth of strain $\mathrm{K}$ in vitro and in vivo in order to construct various predictive growth models and to adequately formulate this strain.

Acknowledgements We thank the Royal Station in GORSEM for this collaboration and all those who provided technical assistance. This research was supported by DGA-DGTRE, the Walloon Region (Belgium), and the Academic Agency of Francophonia (AUF).

\section{References}

Benbow, J. M., \& Sugar, D. (1999). Fruit surface colonisation and biological control of postharvest diseases of pear by preharvest yeast applications. Plant Disease, 83, 839-844.

Chand-Goyal, T., \& Spotts, R. A. (1996). Enumeration of bacterial and yeast colonists of apple fruits and identification of epiphytic yeasts on pear fruits in the Pacific Northwest United States. Microbiological Research, 151, $427-432$.
De Clercq, D., Cognet, S., Pujol, M., Lepoivre, P., \& Jijakli, M. H. (2003). Development of a SCAR marker and a semiselective medium for specific quantification of Pichia anomala strain $\mathrm{K}$ on apple fruit surfaces. Postharvest Biology and Technology, 29, 237-247.

Droby, S., Wisniewski, M. E., Cohen, L., Weiss, B., Touitou, D., Eliam, Y., et al. (1997). Influence of $\mathrm{CaCl} 2$ on Penicillium digitatum, grapefruit peel tissue, and biocontrol activity of Pichia guillermondii. Phytopathology, 87, 310-315.

Elad, Y., \& Kirshner, B. (1992). Establishment of active Trichoderma population in the phylloplane and its effect on grey mould (Botrytis cinerea). Phytoparasitica, 20, 137S-141S.

Guetsky, R., Shtienberg, D., Elad, Y., \& Dinoor, A. (2001). Combining biocontrol agents to reduce the variability of biological control. Phytopathology, 91, 621-627.

Ippolito, A., \& Nigro, F. (2000). Impact of preharvest application of biological control agents on postharvest diseases of fresh fruits and vegetables. Crop Protection, 19, 715-723.

Janisiewicz, W. J. (1988). Biological control of diseases of fruits. In K. G. Mukerji, \& K. L. Garg (Eds.), Biocontrol of plant diseases (pp. 153-165). Boca Raton, FL: CRC.

Janisiewicz, W. J., \& Korsten, L. (2002). Biological control of post-harvest diseases of fruits. Annual Review of Phytopathology, 40, 411-441.

Jijakli, M. H. (1996). Etude des propriétés antagonistes de deux souches de levures vis-à-vis de Botrytis cinerea Pres. sur pommes en conservation. Dissertation, Gembloux, Faculté Universitaire des Sciences Agronomiques, 173p.

Jijakli, M. H., Dickburt, C., De Clercq, D., \& Lepoivre, P. (2002). Application de Pichia anomala souche K, 1,3Glucanes et chlorure de calcium pour le contrôle des maladies de conservation des pommes en conditions proches de la pratique. In: $2^{\text {ème }}$ Conférence Internationale sur les moyens alternatifs contre les organismes nuisibles aux végétaux. (pp. 436-445) Palais du Nouveau siècle, Lille-France.

Jijakli, M. H., Grevesse, C., \& Lepoivre, P. (1999). Yeast species for biocontrol of apple postharvest disease: An encouraging case of study for practical use. In K. G. Mukerji, et al. (Ed.), Biotechnological approaches in biocontrol of plant pathogens (pp. 31-49). New York: Kluwer Academic.

Jijakli, M. H., \& Lepoivre, P. (1998). Characterisation of an exo- $\beta$-1,3-glucanase produced by Pichia anomala strain $\mathrm{K}$, antagonist of Botrytis cinerea on apples. Phytopathology, 88, 335-343.

Jijakli, M. H., Lepoivre, P., Tossut, P., \& Thonard, P. (1993). Biological control of Botrytis cinerea and Penicillium sp. on post-harvest apples by two antagonistic yeasts. Mededelingen van de Faculteit landbouwwetenschappen Rijksuniversiteit Gent, 58, 1349-1358.

Kovach, J., Petzoldt, R., \& Harman, G. E. (2000). Use of honey bees and bumble bees to disseminate Trichoderma harzianum 1295-22 to strawberries for Botrytis control. Biological Control, 18, 235-242.

Lahlali, R. (2006). Etude et modélisation du comportement écologique de deux agents pathogènes de conservation des pommes $P$. expansum Link et $B$. cinerea Pers. et deux de levures Pichia anomala (souche K) et Candida oleophila 
(souche $\mathrm{O}$ ) antagonistes vis-à-vis de ces pathogènes des pommes en conservation. Dissertation, Gembloux, Faculté Universitaire des Sciences Agronomiques, 155p.

Lakshminarayana, S., Sommer, N. F., Polito, V., \& Fortlage, R. J. (1987). Development of resistance to infection by Botrytis cinerea and Penicillium expansum in wounds of mature apple fruit. Phytopathology, 77, 1674-1678.

Leibinger, W., Breuker, B., Hahn, M., \& Mendgen, K. (1997). Control of postharvest pathogens and colonisation of the apple surface by antagonistic microorganisms in the field. Phytopathology, 87, 1103-1110.

Massart, S., De Clercq, D., Salmon, M., Dickburt, C., \& Jijakli, M. H. (2005). Development of real-time PCR using Minor Groover Binding probe to monitor the biological control agent Candida oleophila (strain O). Journal of Microbiological Methods, 60, 73-82.

McLaughlin, R. J., Wisniewski, M. E., Wilson, C. L., \& Chalutz, E. (1990). Effect of inoculation concentration and salt solutions on biological control of postharvest diseases of apple with Candida spp. Phytopathology, 80, 456-461.

Mercier, J., \& Wilson, C. L. (1994). Colonisation of apple wounds by naturally occurring microflora and introduced Candida oleophila and their effect on infection by Botrytis cinerea during storage. Biological Control, 4, 138-144.

Smilanick, J. L. (1994). Strategies for the isolation and testing of biocontrol agents. In C. L. Wilson, \& M. E. Wisniewski (Eds.), Biological control of postharvest diseases, theory and practice (pp. 25-42). Boca Raton, FL: CRC.

Spotts, R. A., \& Cervantes, L. A. (1986). Populations, pathogenicity, and benomyl resistances of Botrytis spp,
Penicillium spp, and Mucor piriformis in packinghouses. Plant Disease, 70, 106-108.

Spotts, R. A., Sanderson, P. G., Lennox, C. L., Sugar, D., \& Cervantes, L. A. (1998). Wounding, wound healing and staining of mature pear fruit. Postharvest Biology and Technology, 13, 27-36.

Sutton, J. C., Li, D., Peng, G., Yu, H., Zhang, P., \& Valdebenito-Sanhueza, R. M. (1997). Gliocladium roseum, a versatile adversary of Botrytis cinerea in crops. Plant Disease, 81, 316-328.

Teixidõ, N., Usall, J., \& Viñas, I. (1999). Efficacy of preharvest and postharvest Candida sake biocontrol treatments to prevent blue mould on apples during cold storage. International Journal of Food Microbiology, 50, 203-210.

Tronsmo, A., \& Dennis, C. (1977). The use of Trichoderma species to control strawberry fruit rots. Netherlands Journal of Plant Pathology, 83, 449-455.

Viñas, I., Vallverdu, N., Monallao, S., Usall, J., \& Sanchis, V. (1993). Imazalil resistent Pencillium isolated from Spanich apples packinghouses. Mycopathologia, 123, 27-33.

Wilson, C. L., Wisniewski, M. E., Droby, S., \& Chalutz, E. (1993). A selection strategy for microbial antagonists to control postharvest diseases of fruits and vegetables. Scientia Horticulturae, 53, 183-189.

Wisniewski, M., Droby, S., Chalutz, E., \& Eliam, Y. (1995). Effects of $\mathrm{Ca}^{2+}$ and $\mathrm{Mg}^{2+}$ on Botrytis cinerea and Penicillium expansum in vitro and on the biocontrol activity of Candida oleophila. Plant Pathology, 44, 1016-1024.

Wisniewski, M. E., \& Wilson, C. L. (1992). Biological control of postharvest diseases of fruits and vegetables: Recent advances. HortScience, 27, 94-98. 